\title{
Meta-analysis of recommended digestible lysine levels for primiparous lactating sows
}

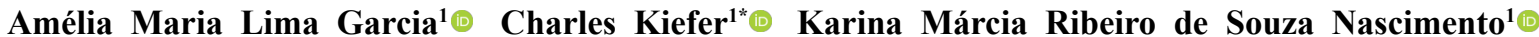 Cheila Roberta Lehnen ${ }^{2}(-)$ Luciano Hauschild $^{3}\left(\right.$ Camilla Mendonça Silva $^{1}$ (1) Stephan Alexander da Silva Alencar ${ }^{1}$ Gabriela Puhl Rodrigues ${ }^{1}{ }^{\circledR}$}

${ }^{1}$ Universidade Federal de Mato Grosso do Sul (UFMS), 79070-900, Campo Grande, MS, Brasil. E-mail: charles.kiefer@ufms.br. "Corresponding author.

${ }^{2}$ Universidade Estadual de Ponta Grossa (UEPG), Ponta Grossa, PR, Brasil.

${ }^{3}$ Universidade Estadual Paulista (UNESP), Jaboticabal, SP, Brasil.

ABSTRACT: A meta-analysis was carried out to evaluate the recommended levels of digestible lysine and its influence on the productive performance of primiparous lactating sows. The database consisted of 26 publications, 138 diets and 3,820 sows was developed from articles on the association between, lysine, crude protein and lactating primiparous sows. The digestible lysine levels of the studies ranged from 0.22 to $1.43 \%$ with average values of $0.85 \%$ digestible lysine in the diet, with consumption of $41.25 \mathrm{~g}$ day ${ }^{-1}$. The digestible lysine intake of sows was positively correlated $(P<0.05)$ with feed intake, essential amino acids, crude protein, metabolizable energy, body weight loss sows, milk production, number and weight of piglets at weaning. Digestible lysine intake showed negative correlation $(P<0.05)$ with backfat thickness at weaning and weaning to oestrus interval. It was observed a quadratic effect $(P<0.01)$ of body weight loss sow and daily weight gain of piglets and a quadratic effect $(P<0.01)$ in the weight of piglets at weaning due to increased dietary lysine level. The level of $1.04 \%$ of digestible lysine indicates less weight loss sows. The greater weight of piglets at weaning and increased daily weight gain of piglets was verified with the addition of 1.30 and $1.07 \%$ digestible lysine in the diet, respectively.

Key words: amino acids, nutrition, parity order, sows.

Meta-análise dos níveis de lisina digestível recomendados em dietas de porcas primíparas lactantes

RESUMO: Realizou-se a meta-análise com o objetivo de determinar o nivel recomendado de lisina digestível e sua influência sobre o desempenho produtivo de porcas primíparas lactantes. A base de dados composta por 26 publicações, 138 dietas e 3.820 fêmeas foi desenvolvida a partir de artigos sobre a associação entre, lisina, proteina bruta e porcas primíparas lactantes. Os níveis de lisina digestivel dos estudos variaram de 0,22 a 1,43\% com valores médios de 0,85\% de lisina digestivel nas dietas, com consumo de 41,25 $\mathrm{g}$ dia ${ }^{-1}$. O consumo de lisina digestivel das porcas apresentou correlação positiva $(P<0,05)$ com o consumo de ração, aminoácidos essenciais, proteina bruta, energia metabolizável, perda de peso corporal da porca, produção de leite, número e peso de leitões ao desmame. O consumo de lisina indicou correlação negativa $(P<0,05)$ para espessura de toucinho ao desmame e intervalo desmame-cio. Observou-se efeito quadrático $(P<0,01)$ da perda de peso corporal da porca e ganho de peso diário dos leitões e efeito quadrático $(P<0,01)$ do peso dos leitões ao desmame em função do aumento do nivel de lisina da dieta. O nivel de 1,04\% de lisina digestível indica a menor perda de peso da porca. O maior peso dos leitões ao desmame e maior ganho de peso diário dos leitões é verificado com a inclusão de 1,30 e 1,07\% de lisina digestível na dieta, respectivamente. Palavras-chave: aminoácidos, fêmeas suinas, nutrição, ordem de parto.

\section{INTRODUCTION}

Sow productivity has increased considerably in recent years, mainly owing to an increase in litter size, which has resulted in an increased metabolic demand for nutrients to support fetal growth and colostrum and milk production
(TOKACH et al., 2019). However, this increase in nutritional requirements has not been accompanied by the pattern of sow intake, thus, sows undergo excessive mobilization of body protein during lactation (YANG et al., 2000a). This can affect the size of the subsequent litter via the reduction of follicular development (CLOWES et al., 2003). 
Thus, the establishment of nutritional requirements for lactating sows is important to minimize the mobilization of body reserves (GOURLEY et al., 2017). Among the amino acids required by lactating sows, more than $70 \%$ are destined for the production of milk protein (PEDERSEN et al., 2016); therefore, the adequate consumption of amino acids and protein may increase milk production (STRATHE et al., 2017).

Among the amino acids, lysine stands out for its direct role in protein synthesis and as the first limiting amino acid in diets based on corn and soybean (GOURLEY et al., 2017), being used as a reference in the formulation (COTA et al., 2003). However, there is wide variation in the recommendations for lysine for lactating sows that can be attributed to several factors such as genetic differences (TU et al., 2010), sow parity (YANG et al., 2009), diet composition (COTA et al., 2003), room temperature (ROSTAGNO et al., 2017) and even the adopted response criteria (BOYD et al., 2000).

Several studies have been carried out to determine the lysine requirements for lactating sows and have generated a large amount of data. Based on this information, it is possible to carry out a meta-analysis that synthesizes study results in a reproducible and quantifiable manner (LOVATTO et al., 2007) and without experimental costs. Therefore, a meta-analysis was carried out to evaluate the recommended levels of digestible lysine and its influence on the productive performance of primiparous lactating sows.

\section{MATERIALS AND METHODS}

A meta-analysis was developed based on data from scientific articles on the association between lysine and crude protein levels in lactating primiparous sows. The methodology for defining the dependent and independent variables and coding the data followed a previous study (LOVATTO et al., 2007). One hundred publications were identified and 69 were excluded after reading the articles. Studies selected to compose the database met the following inclusion criteria: presented the chemical composition of experimental diets and evaluated different levels of amino acids and protein in diets of lactating sows.

The database consisted of 26 publications (KNABE et al., 1996; RICHERT et al., 1997; ZAK et al., 1998; KOKETSU et al., 1998; SAUBER et al., 1998; TOUCHETTE et al., 1998; DOURMAD et al., 1998; KUSINA et al., 1999; JONES \& STAHLY, 1999; YANG et al., 2000a; YANG et al., 2000b; COOPER et al., 2001b; MEJIA-GUADARRAMA et al., 2002; COTA et al., 2003; CLOWES et al., 2003; GOURDINE et al., 2004; QUESNEL et al., 2005; PAIVA et al., 2005; GILL, 2006; HEO et al., 2008; OELKE et al., 2008; YANG et al., 2009; SILVA et al., 2009; HAESE et al., 2010; OELKE et al., 2010; XUE et al., 2012), with a total of 138 diets and 3,820 primiparous lactating sows, with average birth weight of $179.85 \pm 23.68$ $\mathrm{kg}$. The average duration of lactation in the evaluated studies was $23.3 \pm 3.93$ days.

Nutritional levels of digestible lysine, threonine, valine, and methionine + cystine, the level of crude protein, and the metabolizable energy used in the diets were estimated according to the centesimal composition of the experimental diets and the nutritional composition of the food, according to the Brazilian tables of nutritional requirements (ROSTAGNO et al., 2011).

Feed, lysine, threonine, valine, methionine + cystine, and crude protein intake; metabolizable energy; and lysine/metabolizable energy ratio were the evaluated response criteria. Lactating sow characteristics (weight at birth and weaning, fat thickness at birth and weaning, weaning-to-estrus interval, and milk production) and productive performance of sows (number of piglets at birth and weaning, weight of piglets, and weight gain at birth and weaning) were also evaluated.

Models for the analysis of variance and covariance used the factors with the highest correlation coefficients and codifications for inter- and intra-experiment effects, as performed in a previous study (LOVATTO et al., 2007). The regression equations were obtained through the analysis of variance and covariance.

\section{RESULTS AND DISCUSSION}

Digestible lysine levels in the studies ranged from 0.22 to $1.43 \%$, with average values of $0.85 \%$ of digestible lysine in the diets, with an intake of $41.25 \mathrm{~g} \mathrm{day}^{-1}$ (Table 1). Additionally, the diets contained mean values of $16.76 \%$ crude protein, $0.51 \%$ digestible methionine + cystine, $0.57 \%$ digestible threonine, and $0.74 \%$ digestible valine, and 3,317 $\mathrm{Kcal} \mathrm{kg}^{-1}$ of metabolizable energy. For these diets, the mean lysine/metabolizable energy ratio was 2.55 .

From these results, it is possible to infer that there is high variation among the recommendations of digestible lysine for the diets of primiparous lactating sows. These variations can be attributed to several factors, such as genetic lines (TU et al., 2010), sow parity (YANG et al., 2009), diet 
Table 1 - Calculated composition of diets used in studies of lysine in lactating primiparous.

\begin{tabular}{|c|c|c|c|c|c|c|}
\hline Variables & $\mathrm{N}^{\mathrm{o}}$ of diets & Average & Minimum & Maximum & RSD & $\mathrm{CV}$ \\
\hline ME, Kcal kg-1 & 155 & 3,317 & 2,385 & 3,625 & 199 & 6.02 \\
\hline Crude protein, $\%$ & 155 & 16.76 & 5.00 & 28.25 & 4.15 & 24.7 \\
\hline Digestible lysine, $\%$ & 155 & 0.85 & 0.22 & 1.43 & 0.25 & 29.4 \\
\hline Digestible methionine + cystine, $\%$ & 155 & 0.51 & 0.14 & 0.88 & 0.12 & 24.4 \\
\hline Digestible threonine, $\%$ & 155 & 0.57 & 0.17 & 1.02 & 0.15 & 26.6 \\
\hline Digestible valine, $\%$ & 155 & 0.74 & 0.21 & 1.45 & 0.20 & 27.2 \\
\hline Digestible lysine:EM ratio & 155 & 2.55 & 0.69 & 4.14 & 0.71 & 28.0 \\
\hline
\end{tabular}

${ }^{\mathrm{RSD}}$ Residual standard deviation. ${ }^{\mathrm{CV}}$ Coefficient of variation. ${ }^{\mathrm{ME}}$ Metabolizable energy.

composition (COTA et al., 2003), room temperature (ROSTAGNO et al., 2017), and even the adopted response criteria (BOYD et al., 2000).

According to the Brazilian tables of nutritional requirements (ROSTAGNO et al., 2011), the nutritional recommendation for lactating sows at a body weight of $180 \mathrm{~kg}$ with a weight loss of $0.5 \mathrm{~kg} \mathrm{day}^{-1}$ to nurse a litter with a weight gain of $2.0 \mathrm{~kg}$ day $^{-1}$ is $19.84 \%$ crude protein and $1.007 \%$ digestible lysine and recommended intake of $45.5 \mathrm{~g} \mathrm{day}^{-1}$ digestible lysine. In a recent publication (ROSTAGNO et al., 2017), the nutritional recommendation for lactating sows at a body weight of $180 \mathrm{~kg}$ with weight loss of $0.5 \mathrm{~kg}^{-1 a y^{-1}}$ and litter weight gain of $2.8 \mathrm{~kg} \mathrm{day}^{-1}$, is $21.20 \%$ crude protein and $1.075 \%$ digestible lysine and the recommended intake of $64.5 \mathrm{~g} \mathrm{day}^{-1}$ digestible lysine.

To analyze the recommendations of the nutritional levels of lysine, the different requirements of individual lactating sows to promote litter growth and minimize the mobilization of body tissue must be considered. Generally, the requirement for lysine to minimize the loss of muscle mass during lactation and improve subsequent reproductive performance is higher than that for milk production and litter development (PAIVA et al., 2005). Thus, recent studies have tended to recommend higher levels of lysine in the diet of lactating sows than older studies. This development is reflected in the recommended nutritional requirements between ROSTAGNO et al. (2011) and ROSTAGNO et al. (2017).

Feed intake of the primiparous lactating sows ranged from 1.92 to $7.20 \mathrm{~kg} \mathrm{day}^{-1}$, with an average value of $4.85 \mathrm{~kg} \mathrm{day}^{-1}$, with consumption of 41.25 $\mathrm{g} \mathrm{day}^{-1}$ of digestible lysine (Table 2). Additionally, the studies showed average intake values of 16,073 Kcal day ${ }^{-1}$ of metabolizable energy, 804.62 g day $^{-1}$ of crude protein, $24.75 \mathrm{~g}$ day $^{-1}$ of digestible methionine + cystine, $27.51 \mathrm{~g} \mathrm{day}^{-1}$ of digestible threonine, and $35.93 \mathrm{~g} \mathrm{day}^{-1}$ of digestible valine. These average values are similar to those recommended by ROSTAGNO et al. (2011), in which $180 \mathrm{~kg}$ sows

Table 2 - Calculated nutrient intake of diets used in studies of lysine in lactating primiparous.

\begin{tabular}{|c|c|c|c|c|c|c|}
\hline Intake & $\mathrm{N}^{0}$ of diets & Average & Minimum & Maximum & RSD & $\mathrm{CV}$ \\
\hline Ration, $\mathrm{kg} \mathrm{day}^{-1}$ & 155 & 4.85 & 1.92 & 7.20 & 1.24 & 25.62 \\
\hline ME, Kcal day ${ }^{-1}$ & 155 & 16,073 & 6,280 & 24,444 & 4.20 & 26.14 \\
\hline Crude protein, $\mathrm{g}_{\text {day }}{ }^{-1}$ & 155 & 804.62 & 147.00 & $1,329.84$ & 243 & 30.15 \\
\hline Digestible lysine, $\mathrm{g}_{\text {day }}{ }^{-1}$ & 155 & 41.25 & 4.68 & 73.82 & 15.21 & 36.88 \\
\hline Digestible methionine + cystine, $\mathrm{g}$ day $^{-1}$ & 155 & 24.75 & 4.09 & 45.19 & 7.67 & 31.01 \\
\hline Digestible threonine, $\mathrm{g}$ day $^{-1}$ & 155 & 27.51 & 5.00 & 46.87 & 8.60 & 31.28 \\
\hline Digestible valine, $\mathrm{g}$ day $^{-1}$ & 155 & 35.93 & 6.29 & 66.93 & 12.60 & 35.08 \\
\hline
\end{tabular}

${ }^{\mathrm{RSD}}$ Residual standard deviation. ${ }^{\mathrm{CV}}$ Coefficient of variation. ${ }^{\mathrm{ME}}$ Metabolizable energy. 
should consume $4.52 \mathrm{~kg}$ day $^{-1}$ of feed, 15,369 Kcal day ${ }^{-1}$ of metabolizable energy, and $45.5 \mathrm{~g} \mathrm{day}^{-1}$ of digestible lysine. However, they are less than the recommendations presented by ROSTAGNO et al. (2017), in which $180 \mathrm{~kg}$ sows should consume 6.0 $\mathrm{kg}$ day $^{-1}$ of feed, 20,400 Kcal day ${ }^{-1}$ of metabolizable energy, and $64.5 \mathrm{~g} \mathrm{day}^{-1}$ of digestible lysine.

Sow feed intake is one of the most important variables in lactation and must be constantly evaluated as it affects the availability of amino acids, which can determine whether a sow meets their nutritional requirements. It is influenced by sow parity (YOUNG et al., 2004), body composition (COOPER et al., 2001a), genetics (SAUBER et al., 1998), and environmental temperature (KIEFER et al., 2012). Currently, it is normal for lactating primiparous sows to achieve daily feed intake of less than the predetermined ideal values (COTA et al., 2003), and less than $18 \%$ of sows show the ideal pattern of feed intake during lactation (KOKETSU et al., 1996).

The digestible lysine intake of sows showed a positive correlation $(\mathrm{P}<0.05)$ with feed intake, essential amino acids, crude protein, metabolizable energy, sow body weight loss, milk production, and number and weight of piglets at weaning (Table 3). Correlations between the digestible lysine intake and the essential amino acids observed can be explained by the formulation of the diets, which are based on the ideal protein content and estimate various amino acid needs from the lysine requirement (TUITOEK et al., 1997).

Different ideal protein patterns are suggested for lactating sows according to the degree of muscle tissue mobilization. For sows with low voluntary feed intake and substantial tissue mobilization, the critical amino acid is threonine, whereas for those with high feed intake and little tissue mobilization, valine becomes more important. However, lysine remains the main and the first limiting amino acid in both cases (KIM et al., 2001; KIM et al., 2005).

However, COTA et al. (2003) showed a negative correlation between the level of lysine in the diet and sow body weight loss. Furthermore, HEO et al. (2008) observed that higher levels of lysine in the diet of primiparous lactating sows resulted in an increase in the weight of the litter at weaning compared with lactating sows with lower levels of lysine in the diet.

The digestible lysine intake in the present study had a negative correlation $(\mathrm{P}<0.05)$ with fat thickness at weaning and weaning-to-estrus interval; however, levels of digestible lysine did not correlate $(\mathrm{P}>0.05)$ with performance and weight gain of the

Table 3 - Correlation coefficients between lysine levels and nutritional, body and litter variables of lactating primiparous.

\begin{tabular}{|c|c|c|c|c|c|c|c|c|}
\hline \multirow[t]{2}{*}{ Answer } & & \multicolumn{7}{|c|}{ - } \\
\hline & FI & Lys $^{1}$ & Threo $^{1}$ & $\mathrm{Val}^{1}$ & Meth + Cys $^{1}$ & $\mathrm{CP}$ & & ME \\
\hline \%Lys & 0.072 & 0.730 & 0.694 & 0.534 & 0.598 & 0.642 & & 0.152 \\
\hline $\mathrm{P}$ & 0.37 & 0.00 & 0.00 & 0.00 & 0.00 & 0.00 & & 0.06 \\
\hline LysI & 0.710 & - & 0.901 & 0.799 & 0.873 & 0.880 & & 0.754 \\
\hline $\mathrm{P}$ & 0.00 & - & 0.00 & 0.00 & 0.00 & 0.00 & & 0.00 \\
\hline \multirow{2}{*}{ Answer } & \multicolumn{3}{|c|}{ - } & \multicolumn{4}{|c|}{--1 } & \\
\hline & Farrowing & Weaning & Loss & Farrowing & Weaning & Loss & & WEl, day \\
\hline \%Lys & 0.205 & 0.311 & 0.280 & -0.221 & -0.273 & 0.027 & & -0.182 \\
\hline $\mathrm{P}$ & 0.02 & 0.00 & 0.00 & 0.02 & 0.00 & 0.78 & & 0.12 \\
\hline LysI & 0.370 & 0.534 & 0.392 & -0.354 & -0.252 & 0.264 & & -0.404 \\
\hline $\mathrm{P}$ & 0.00 & 0.00 & 0.00 & 0.00 & 0.00 & 0.01 & & 0.00 \\
\hline \multirow{2}{*}{ Answer } & & \multicolumn{2}{|c|}{-.00 } & \multicolumn{5}{|c|}{ 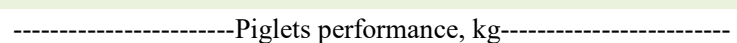 } \\
\hline & MP, $\mathrm{kg}_{\text {day }}{ }^{-1}$ & Birth & Weaning & Birth & \multicolumn{2}{|c|}{ Weaning } & \multicolumn{2}{|c|}{ Gain, $\mathrm{kg}_{\text {day }}{ }^{-1}$} \\
\hline \%Lys & 0.284 & -0.018 & 0.229 & -0.034 & 0.179 & \multicolumn{3}{|c|}{0.067} \\
\hline $\mathrm{P}$ & 0.00 & 0.84 & 0.01 & 0.72 & 0.05 & \multicolumn{3}{|c|}{0.46} \\
\hline LysI & 0.408 & 0.113 & 0.408 & -0.056 & 0.228 & \multicolumn{3}{|c|}{-0.120} \\
\hline $\mathrm{P}$ & 0.00 & 0.19 & 0.00 & 0.55 & 0.01 & \multicolumn{3}{|c|}{0.21} \\
\hline
\end{tabular}

${ }^{\%}$ Lys Lysine level; ${ }^{\mathrm{P}} 5 \%$ significance level; ${ }^{\text {FI }}$ Feed intake; ${ }^{\text {Lys }}$ Lysine intake; ${ }^{\text {Threo }}$ Threonine intake; ${ }^{\text {Val }}$ Valine intake; ${ }^{\text {Meth }+ \text { Cys }}$ Methionine + cystine intake; ${ }^{\mathrm{CP}}$ Crude protein; ${ }^{\mathrm{ME}}$ Metabolizable energy; ${ }^{\mathrm{wEI}}$ Weaning-to-estrus interval; ${ }^{\mathrm{MP}}$ Milk production; ${ }^{1}$ Calculated amino acid intake. 
piglets. The correlation between digestible lysine intake and fat thickness can be explained by the increased intake of lysine resulting in increased milk production and, consequently, an increase in the number of weaned piglets. The increase in milk production, observed in larger litters, results in increased energy requirements and, in situations where this increase is not met by the intake of nutrients, there is an increase in the mobilization of body reserves, resulting in a reduction in the fat thickness. This response has also been observed by GILL (2006), in which higher levels of lysine decreased fat thickness, and MAES et al. (2004), in which sows that weaned a greater number of piglets showed a greater loss of fat thickness during lactation. Estimates by TOKACH et al. (2019) also show this response, that the increase in daily milk production, related to the increase in the number of piglets in the litter, increases the mobilization of body protein and fat and; consequently, increases weight loss during lactation.
The equations that best explain the productive performance of the sows present as covariables, in addition to the levels of digestible lysine and the sow's weight at birth (Table 4). There was a quadratic effect between sow body weight loss and daily weight gain of the piglets $(\mathrm{P}<0.01)$ and piglet weight at weaning $(\mathrm{P}<0.01)$ owing to the increase in the level of lysine in the diet.

Diets with $1.04 \%$ digestible lysine showed the lowest daily weight loss $\left(0.57 \mathrm{~kg} \mathrm{day}^{-1}\right)$, whereas those with 1.30 and $1.07 \%$ digestible lysine resulted in a greater weight of piglets at weaning and greater daily weight gain of piglets, respectively. We can infer that the recommendations for the nutritional requirement of digestible lysine may vary for the same data set according to the response criteria used, as suggested by BOYD et al. (2000) and GOURLEY et al. (2019). Recommendation calculated in this study $(1.04 \%$ digestible lysine) is slightly higher than the $1.01 \%$ digestible lysine established by ROSTAGNO et al. (2011) and slightly lower than the

Table 4 - Equations obtained by analysis of variance-covariance to estimate the impact of lysine level on the diet of lactating primiparous.

\begin{tabular}{|c|c|c|c|c|}
\hline Variable & Equations & CVR & $\mathrm{R}^{2}$ & $\mathrm{P}^{1}$ \\
\hline \multicolumn{5}{|c|}{ 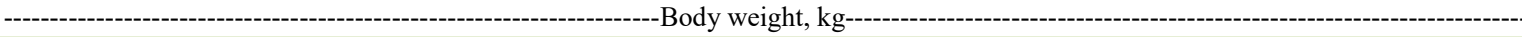 } \\
\hline Farrowing & 181.48-1.33Lys & 6.91 & 0.93 & ns \\
\hline Weaning & 21.1+11.1Lys +0.749 BW farrowing & 7.10 & 0.94 & *** \\
\hline Loss & $-10.2+60.3$ Lys-29.0Lys²-0.184 BW farrowing & 10.3 & 0.78 & *** \\
\hline \multicolumn{5}{|c|}{ 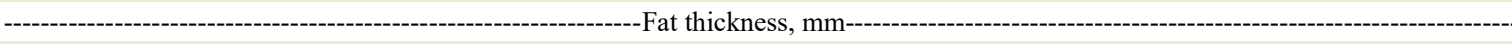 } \\
\hline Farrowing & 20.75-0.61Lys & 2.67 & 0.80 & ns \\
\hline Weaning & 19.6-3.21Lys & 2.73 & 0.64 & ${ }^{* *}$ \\
\hline Loss & -1.294-2.46Lys & 1.63 & 0.75 & ** \\
\hline Milk production, $\mathrm{kg}$ day $^{-1}$ & $6.501+1.695$ Lys & 0.68 & 0.94 & *** \\
\hline \multicolumn{5}{|c|}{ - } \\
\hline Born & $10.06+0.0091$ Lys & 0.18 & 0.99 & $\mathrm{~ns}$ \\
\hline Weaned & $9.47+0.108$ Lys & 0.31 & 0.88 & ns \\
\hline \multicolumn{5}{|c|}{ 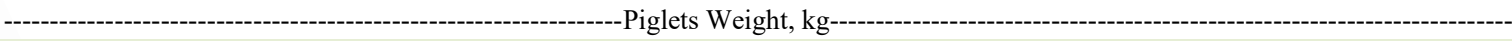 } \\
\hline Farrowing & $1.456+0.266$ Lys & 0.62 & 0.72 & ns \\
\hline \multirow[t]{2}{*}{ Weaning } & $5.648+0.613$ Lys & 0.41 & 0.86 & ** \\
\hline & $4.724+2.92 \mathrm{Lys}-1.12 \mathrm{Lys}^{2}$ & 0.40 & 0.86 & ** \\
\hline \multirow{2}{*}{ Weight gain, $\mathrm{kg}_{\text {day }}{ }^{-1}$} & $0.3281+0.0554 \mathrm{Lys}$ & 0.03 & 0.99 & *** \\
\hline & $0.2594+0.2399$ Lys-0.112 Lys $^{2}$ & 0.03 & 0.99 & *** \\
\hline ---------- & 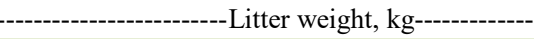 & -------.. & ------- & ----- \\
\hline Born & $14.909+0.312$ Lys & 0.68 & 0.94 & ns \\
\hline \multirow[t]{2}{*}{ Weaning } & $53.3+7.52 \mathrm{Lys}$ & 4.38 & 0.89 & *** \\
\hline & $50.4+15.3$ Lys-4.58 Lys $^{2}$ & 4.39 & 0.89 & $\mathrm{~ns}$ \\
\hline Weight gain, $\mathrm{kg}$ day $^{-1}$ & $1.653+0.380 \mathrm{Lys}$ & 0.18 & 0.79 & *** \\
\hline
\end{tabular}

${ }^{1}$ Significance level for the covariate $\%$ Lys: ${ }^{\text {ns }} \mathrm{P}>0,05 ;{ }^{*} \mathrm{P}<0,05 ;{ }^{* *} \mathrm{P}<0,01 ;{ }^{* * *} \mathrm{P}<0,001$; ${ }^{\text {RSD }}$ Residual standard deviation; ${ }^{\text {ns }}$ not significant;

${ }^{\mathrm{BW}}$ Body weight; ${ }^{\text {Lys }}$ Lysine level. 
current recommendation of the new Brazilian tables (ROSTAGNO et al., 2017), which suggested a diet of $1.075 \%$ digestible lysine, with a similar pattern of estimated body weight loss during lactation $(0.50 \mathrm{~kg}$ day $\left.^{-1}\right)$. A level close to that of the present study was established by TU et al. (2010) who recommended $1.05 \%$ lysine for less loss of fat thickness and greater number and weight of weaned piglets.

\section{CONCLUSION}

In view of the variability in the database of this meta-analysis, the level of digestible lysine recommended varies according to the response criterion adopted. However, it is possible to recommend $1.04 \%$ for the lowest sow weight loss, $1.30 \%$ for the greatest weight of piglets at weaning, and $1.07 \%$ for the greatest daily weight gain of piglets.

\section{ACKNOWLEDGEMENTS}

The authors thank the Conselho Nacional de Desenvolvimento Científico e Tecnológico (CNPq), Universidade Federal de Mato Grosso do Sul (UFMS), and Coordenação de Aperfeiçoamento de Pessoal de Nível Superior - Brasil (CAPES; Finance Code 001) for the financial support in the execution of the research project.

\section{DECLARATION OF CONFLICT OF INTERESTS}

The authors declare no conflict of interest. The funding sponsors had no role in the design of the study; in the collection, analyses, or interpretation of data; in the writing of the manuscript, and in the decision to publish the results.

\section{AUTHORS' CONTRIBUTIONS}

All authors contributed equally for the conception and writing of the manuscript. All authors critically revised the manuscript and approved of the final version.

\section{REFERENCES}

BOYD, R. D. et al. Recent advances in amino acid and energy nutrition of prolific sows-review. Asian-Australasian Journal of Animal Sciences, v.13, p.1638-1652, 2000. Available from: $<$ https://www.ajas.info/upload/pdf/13-233.pdf >. Accessed: Feb. 10, 2020. doi: 10.5713/ajas.2000.1638.

CLOWES, E. J. et al. Parturition body size and body protein loss during lactation influence performance during lactation and ovarian function at weaning in first-parity sows. Journal of Animal Science, v.81, p.1517-1528, 2003. Available from: $<$ https://doi. org/10.2527/2003.816151-7x>. Accessed: Feb. 08, 2019. doi: $24010.2527 / 2003.8161517 x$.

COOPER, D. R. et al. Effect of energy and lysine intake in gestation on sow performance. Journal of Animal Science, v.79, p.2367-2377, 2001a. Available from: < https://doi. org/10.2527/2001.7992367x>. Accessed: Mar. 25, 2019. doi: $10.2527 / 2001.7992367 x$.

COOPER, D. R. et al. Effect of nutrient intake in lactation on sow performance: determining the threonine requirement of the high-producing lactating sow. Journal of Animal Science, v.79, p.2378-2387, 2001b. Available from: <https://doi. org/10.2527/2001.7992378x>. Accessed: Mar. 20, 2019. doi: $10.2527 / 2001.7992378 x$.

COTA, T. S. et al. Níveis de lisina em ração de lactação para fêmeas suínas primíparas. Revista Brasileira de Zootecnia, v.32, p.115122, 2003. Available from: < http://dx.doi.org/10.1590/S151635982003000100015>. Accessed: Mar. 12, 2019. doi: 10.1590/ S1516-35982003000100015.

DOURMAD, J. Y. et al. Effect of protein and lysine supply on performance, nitrogen balance, and body composition changes of sows during lactation. Journal of Animal Science, v.76, p.542-550, 1998. Available from: $<\mathrm{http}: / / \mathrm{dx}$.doi.org/10.2527/1998.762542x>. Accessed: Mar. 05, 2019. doi: 10.2527/1998.762542x.

GILL, B. P. Body composition of breeding gilts in response to dietary protein and energy balance from thirty kilograms of body weight to completion of first parity. Journal of Animal Science, v.84, p.1926-1934, 2006. Available from: <https://doi. org/10.2527/jas.2005-203>. Accessed: Jan. 23, 2019. doi: 10.2527/ jas.2005-203.

GOURLEY, K. M. et al. Determining the impact of increasing standardized ileal digestible lysine for primiparous and multiparous sows during lactation. Translational Animal Science, v.1, p.426436, 2017. Available from: <https://academic.oup.com/tas/ article/1/4/426/4780399>. Accessed: Feb. 10, 2020. doi: 10.2527/ $\operatorname{tas} 2017.0043$.

GOURDINE, J. L. et al. Effects of season and parity on performance of lactating sows in a tropical climate. Animal Science, v.79, p.273-282, 2004. Available from: <https://doi. org/10.1017/S1357729800090135>. Accessed: Jan. 26, 2019. doi: $10.1017 / \mathrm{S} 1357729800090135$.

HAESE, D. et al. Validation of the relationships of methionine, threonine, tryptophan and valine amino acids with the digestible lysine in the ideal protein in feedings for lactating sows. Revista Brasileira de Zootecnia, v.39, p.1497-1502, 2010. Available from: <http://dx.doi.org/10.1590/S1516-35982010000700015>. Accessed: Jan. 30, 2019. doi: 10.1590/S1516-35982010000700015.

HEO, S. et al. Effects of dietary energy and lysine intake during late gestation and lactation on blood metabolites, hormones, milk composition and reproductive performance in primiparous sows. Canadian Journal of Animal Science, v.88, p.247-255, 2008. Available from: < https://doi.org/10.4141/CJAS07060>. Accessed: Feb. 15, 2019. doi: 10.4141/CJAS07060.

JONES, D. B.; STAHLY, T. S. Impact of amino acid nutrition during lactation on body nutrient mobilization and milk nutrient output in primiparous sows. Journal of Animal Science, v.77, p.1513-1522, 1999. Available from: <https://doi.org/10.2527/1999.7761513x>. Accessed: Feb. 22, 2019. doi: 282 10.2527/1999.7761513x.

KIEFER, C. et al. Evaporative cooling for lactating sows under high ambient temperature. Revista Brasileira de Zootecnia, v.41, p.1180-1185, 2012. Available from: <http://www.scielo.br/pdf/ 
rbz/v41n5/15.pdf $>$. Accessed: Feb. 10, 2020. doi: 10.1590/S151635982012000500015 .

KIM, S. W. et al. Dynamic ideal protein and limiting amino acids for lactating sows: the impact of amino acid mobilization. Journal of Animal Science, v.79, p.2356-2366, 2001. Available from: $<$ https://doi.org/10.2527/2001.7992356x>. Accessed: Apr. 27, 2019. doi: $10.2527 / 2001.7992356 x$.

KIM, S. et al. Ideal protein and dietary amino acid requirements for gestating and lactating sows. Pig News and Information, v.26, p. $89 \mathrm{~N}-99 \mathrm{~N}, 2005$. Available from: <https://www.researchgate. net/publication/228647738 Ideal protein and amino acid requirements_by_gestating_and_lactating_sows $>$. Accessed: Mar. 17, 2019

KNABE, D. H. et al. Supplemental lysine for sows nursing large litters. Journal of Animal Science, v.74, p.1635-1640, 1996 Available from: <https://doi.org/10.2527/1996.7471635x>. Accessed: Apr. 23, 2019. doi: 29610.2527/1996.7471635x.

KOKETSU, Y. et al. Feed intake pattern during lactation and subsequent reproductive performance of sows. Journal of Animal Science, v.74, p.2875-2884, 1996. Available from: <https://doi. org/10.2527/1996.74122875x>. Accessed: Feb. 20, 2019. doi: $30010.2527 / 1996.74122875 x$.

KOKETSU, Y. et al. Influence of lactation length and feed intake on reproductive performance and blood concentrations of glucose, insulin and luteinizing hormone in primiparous sows. Animal Reproduction Science, v.52, p.153-163, 1998. Available from: <https://doi.org/10.1-016/S03784320(98)00093-1>. Accessed: Apr. 15, 2019. doi: 10.1016/ S0378-4320(98)00093-1.

KUSINA, J. et al. Effect of protein intake during gestation and lactation on the lactational performance of primiparous sows Journal of Animal Science, v.77, p.931-941, 1999. Available from: <https://doi.org/10.2527/1999.774931x>. Accessed: Feb. 22, 2019. doi: 10.2527/1999.774931x.

LOVATTO, P. A. et al. Meta analysis in scientific research: a methodological approach. Revista Brasileira de Zootecnia, v.36, p.285-294, 2007. Available from: <http://dx.doi.org/10.1590/ S1516-35982007001000026>. Accessed: Jan. 26, 2019. doi: $10.1590 / \mathrm{S} 1516-35982007001000026$

MAES, D. G. D. et al. Back fat measurements in sows from three commercial pig herds: relationship with reproductive efficiency and correlation with visual body condition score. Livestock Production Science, v.91, p.57-67, 2004. Available from: $<$ https:// doi.org/10.101-6/j.livprodsci.2004.06.015>. Accessed: May, 10 2019. doi: 10.1016/j.livprodsci.2004.06.015.

MEJIA-GUADARRAMA, C. A. et al. Protein (lysine) restriction in primiparous lactating sows: effects on metabolic state, somatotropic axis, and reproductive performance after weaning. Journal of Animal Science, v.80, p.3286-3300, 2002. Available from: <https://doi.org/ 10.2527/2002.80123286x>. Accessed: May, 12, 2019. doi: 326 10.2527/2002.80123286x.

OELKE, C. A. et al. Digestible lysine levels in diets for primiparous lactating sows. Acta Scientiarum. Animal Sciences, v.30, p.299306, 2008. Available from: <http://eduem.uem.br/ojs/index.php/ ActaSciAnimSci/article/download/1626/1626>. Accessed: Feb. 06, 2019.
OELKE, C. A. et al. Lysine for primiparous lactating sows and effect in the performance of the piglets. Archives of Veterinary Science, v.15, p.149-156, 2010. Available from: $<$ https://revistas.ufpr.br/veterinary/article/view/16715/13919>. Accessed: Feb. 12, 2019.

PAIVA, F. P. et al. Lysine in the diet of primiparous lactating sows. Revista Brasileira de Zootecnia, v.34, p.1971-1979, 2005. Available from: <http://dx.doi.org/10.1590/S151635982005000600022>. Accessed: May, 28, 2019. doi: 10.1590/ S1516-35982005000600022.

PEDERSEN, T. F. et al. A two-diet feeding regime for lactating sows reduced nutrient deficiency in early lactation and improved milk yield. Livestock Science, v.191, p.165-173, 2016. Available from: $<$ https://www.sciencedirect.com/science/ article/pii/S1871141316301743>. Accessed: Mar. 05, 2020. doi: 10.1016/j.livsci.2016.08.004.

QUESNEL, H. et al. Dietary protein restriction during lactation in primiparous sows with different live weightsat farrowing: I. Consequences on sow metabolic status and litter growth. Reproduction Nutrition Development, v.45, p.39-56, 2005. Available from: $<$ https://doi.org/10.1051/rnd:2005005>. Accessed: Apr. 15, 2019. doi: 10.1051/rnd:2005005.

RICHERT, B. T. et al. The effect of dietary lysine and valine fed during lactation on sow and litter performance 1, 2. Journal of Animal Science, v.75, p.1853-1860, 1997. Available from: $<$ https://doi.org/10.2527/1997.7571853x>. Accessed: May, 5, 2019. doi: $10.2527 / 1997.7571853 x$.

ROSTAGNO H. S. et al. Tabelas brasileiras para aves e suínos: composição de alimentos e exigências nutricionais. Viçosa (MG): UFV; 2011. 256p.

SAUBER, T. E. et al. Effect of lean growth genotype and dietary amino acid regimen on the lactational performance of sows. Journal of Animal Science, v.76, p.1098-1111, 1998. Available from: <http://dx.doi.org/10.2527/1998.7641098x>. Accessed: Feb. 15, 2019. doi: $10.2527 / 1998.7641098 x$.

SILVA, B. A. N. et al. Effect of floor cooling and dietary amino acids content on performance and behaviour of lactating primiparous sows during summer. Livestock Science, v.120, p.25-34, 2009. Available from: <https://doi.org/10.1016/j.livsci.2008.04.015>. Accessed: Feb. 29, 2019. doi: 10.1016/j.livsci.2008.04.015.

STRATHE, A. V. et al. Increased dietary protein levels during lactation improved sow and litter performance. Animal Feed Science and Technology, v.232, p.169-181, 2017. Available from: <https:// www.sciencedirect.com/science/article/pii/S0377840117304364>. Accessed: Feb. 10, 2020. doi: 10.1016/j.anifeedsci.2017.08.015.

TOKACH, M. D. et al. Review: nutrient requirements of the modern high-producing lactating sow, with an emphasis on amino acid requirements. Animal, v.13, p.2967-2977, 2019. Available from: <https://www.cambridge.org/core/services/aop-cambridgecore/content/view/7CD46DBA9CCAF58BD49899FF8BE4E1 1E/S1751731119001253a.pdf/review_nutrient_requirements_of the modern highproducing lactating sow with an emphasis on_amino_acid_requirements.pdf $>$. Accessed: Feb. 10, 2020. do i: $10 . \overline{1017 / \mathrm{S}} 1751 \overline{7} 31119001253$

TOUCHETTE, K. J. et al. The lysine requirement of lactating primiparous sows. Journal of Animal Science, v.76, p.1091-1097, 
1998. Available from: <https://doi.org/10.25-27/1998.7641091x>. Accessed: Jan. 30, 2019. doi: 10.2527/1998.7641091x.

TU, P. K. et al. Effect of dietary lysine supplement on the performance of Mong Cai sows and their piglets. Asian Australasian Journal of Animal Science, v.23, p.385-395, 2010. Available from: <https://doi.org/10.5713/ajas.2010.90318>. Accessed: Apr. 12, 2019. doi: 10.5713/ajas.2010.90318.

TUITOEK, K. et al. The effect of reducing excess dietary amino acids on growing-finishing pig performance: an elevation of the ideal protein concept. Journal of Animal Science, v.75, p.1575-1583, 1997. Available from: <https://doi.org/10.2527/1997.7561575x $>$. Accessed: Mar. 16, 2019. doi: 10.2527/1997.7561575x.

XUE, L. et al. The effect of the ratio of standardized ileal digestible lysine to metabolizable energy on growth performance, blood metabolites and hormones of lactating sows. Journal of Animal Science and Biotechnology, v.3, p.1-12, 2012. Available from: $<$ https://doi.org/10.1186/2049-1891-3-11>. Accessed: Jan. 18, 2019. doi: 10.1186/2049-1891-3-11.

YANG, H. et al. Effects of dietary lysine intake during lactation on blood metabolites, hormones, and reproductive performance in primiparous sows. Journal of Animal Science, v.78, p.1001-1009, 2000a. Available from: <https://doi.org/10.2527/2000.7841001x > Accessed: Apr. 04, 2019. doi: 10.2527/2000.7841001x.
YANG, H. et al. Lactational and subsequent reproductive responses of lactating sows to dietary lysine (protein) concentration. Journal of Animal Science, v.78, p.348-357, 2000b. Available from: $<$ https://doi.org/10.2527/2000.782348x>. Accessed: May, 04, 2019. doi: $10.2527 / 2000.782348 x$.

YANG, Y. X. et al. Effects of lysine intake during late gestation and lactation on blood metabolites, hormones, milk composition and reproductive performance in primiparous and multiparous sows. Animal Reproduction Science, v.112, p.199-214, 2009. Available from: <https://doi.org/10.1016/j. anireprosci.2008.04.031>. Accessed: Apr. 21, 2019. doi: 10.1016/j. anireprosci.2008.04.031.

YOUNG, M. G. et al. Comparison of three methods of feeding sows in gestation and the subsequent effects on lactation performance. Journal of Animal Science, v.82, p.3058-3070, 2004. Available from: <https://doi. org/10.2527/2004.82103058x>. Accessed: Apr. 13, 2019. doi: $10.2527 / 2004.82103058 x$.

ZAK, L. J. et al. Feeding lactating primiparous sows to establish three divergent metabolic states: I. Associated endocrine changes and post weaning reproductive performance. Journal of Animal Science, v.76, p.1145-1153, 1998. Available from: $<$ https://doi. org/10.2527/1998.7641145x $>$. Accessed: May, 01, 2019. doi: $10.2527 / 1998.7641145 x$ 